\title{
Retraction note: Histopathological features of bone regeneration in a canine segmental ulnar defect model
}

\author{
Rahim Hobbenaghi', Pariya Mahboob², Siamak Saifzadeh ${ }^{3}$, Javad Javanbakht ${ }^{4 *}$, Javad Yaghoobi Yeganeh Manesh ${ }^{5}$, \\ Rasool Mortezaee ${ }^{6}$, Seyed Rashid Touni ${ }^{7}$, Ehsan Hosseini ${ }^{8}$, Shahin Aghajanshakeri ${ }^{9}$, Milad Moloudizargari ${ }^{9}$ \\ and Soheil Javaherypour ${ }^{9}$
}

The Editor-in-Chief and Publisher have retracted this article [1] because the scientific integrity of the content cannot be guaranteed. An investigation by the Publisher found it to be one of a group of articles we have identified as showing evidence suggestive of attempts to subvert the peer review and publication system to inappropriately obtain or allocate authorship. This article showed evidence of plagiarism (most notably from the articles cited [2-5]) and peer review and authorship manipulation.
3. Capo JT, Marcus MS, Shamian B. Treatment of a segmental defect in open radial and ulnar shaft fractures using rhBMP-2 and iliac crest bone graft: a case report. Hand (N Y). 2011;6(4):424-8.

4. Sheller MR, Crowther RS, Kinney JH, Yang J, di Jorio S, Breunig T, Carney DH, Ryaby JT. Repair of rabbit segmental defects with the thrombin peptide, TP508. J Orthop Res. 2004;22(5):1094-9.

5. Nnaji T, Kene R, Chah K, Udegunam S, Ogbanya K, Okpe G. Histopathological evaluation of the osteogenic activity of autologous platelet-rich plasma in experimentally induced ulna defect in dogs. Comp Clin Pathol. 2015;24(6):1593-7.

\begin{abstract}
Author details
${ }^{1}$ Department of Pathology, Faculty of Veterinary Medicine, Urmia University, Urmia, Iran. ${ }^{2}$ Graduate, Faculty of Veterinary Medicine, Urmia University, Urmia, Iran. Institute of Health and Biomedical Innovation, Queensland University of Technology, 60 Musk Avenue, Kelvin Grove, Brisbane, QLD 4059, Australia. ${ }^{4}$ Department of Pathobiology, Faculty of Veterinary Medicine, Tehran University, Tehran, Iran. ${ }^{5}$ Graduate of Islamic Azad University of Shahrekord, Faculty of Veterinary Medicine, Shahrekord University, Shahrekord, Iran. ${ }^{6}$ Student of Ferdowsi University of Mashhad, Faculty of Veterinary Medicine, Ferdowsi University, Mashahd, Iran. ${ }^{7}$ Ph.D Student of Anatomy and Embryology, Faculty of Veterinary Medicine, Urmia University, Urmia, Iran. ${ }^{8}$ Faculty of Para Veterinary Medicine, Ilam University, Ilam, Iran. ${ }^{9}$ Student of Veterinary Medicine, Faculty of Veterinary Medicine, Urmia University, Urmia, Iran.
\end{abstract}

Received: 17 October 2016 Accepted: 19 October 2016

Published online: 02 November 2016

\section{References \\ 1. Hobbenaghi R, Mahboob P, Saifzadeh S, Javanbakht J, Manesh JY, Mortezaee R, Touni SR, Hosseini E, Aghajanshakeri S, Moloudizargari M, Javaherypour S. Histopathological features of bone regeneration in a canine segmental ulnar defect model. Diagn Pathol. 2014;9. \\ 2. Garcia $P$, Holstein $\mathrm{JH}$, Klein $M$, Laschke MW, Matthys $R$, Ignatius $A$, Wildemann B, Lienau J, Peters B, Willie B, Duda G, Claes L, Pohlemann T, Menger MD. Rodent animal models of delayed bone healing and non- union formation: a comprehensive review. Eur Cell Mater. 2013;26:1-12. discussion 12-4.}

\footnotetext{
* Correspondence: javadpatho@gmail.com

${ }^{4}$ Department of Pathobiology, Faculty of Veterinary Medicine, Tehran University, Tehran, Iran
} 